\title{
Espero um ano inteiro até chegar fevereiro: representações do carnaval por três poetas pernambucanos
}

\author{
Taciana Ferreira Soares* \\ Universidade Federal de Pernambuco \\ Recife, Brasil \\ Recebido em: 29/04/2019 \\ Aceito em: 30/07/2019
}

Resumo: Pretende-se, neste trabalho, abordar comparativamente aspectos relacionados ao carnaval encontrados na produção poética de três grandes autores pernambucanos: Manuel Bandeira, Carlos Pena Filho e Ascenso Ferreira, apresentando pontos de convergência e divergência na representação da referida festa popular, analisando os elementos e símbolos escolhidos por eles para dar vida ao carnaval nas suas poesias. Nota-se que, dentre eles, Bandeira é estudado de maneira aprofundada e relevante, enquanto que os outros dois autores, mesmo tendo obras enérgicas, são menos explorados academicamente. O mesmo se percebe do carnaval, enquanto temática no campo das letras e da literatura, frequentemente considerado menos notável nesta área.

Palavras-chave: Manuel Bandeira. Carlos Pena Filho. Ascenso Ferreira. Carnaval.

\begin{abstract}
The aim of this work is to comparatively discuss aspects related to the carnival that are found in the poetic production of three great authors from Pernambuco: Manuel Bandeira, Carlos Pena Filho and Ascenso Ferreira, presenting points of convergence and divergence in the representation of the popular party, analyzing the elements and symbols chosen by them to give life to the carnival in their poetry. Note that, between them, Bandeirais studied in an in-depth and relevant way, while the other two authors, despite having energetic works, are less explored academically. The same is true of carnival, as a theme in the field of languages and literature, often considered of lesser importance in this area.
\end{abstract}

Keywords: Manuel Bandeira. Carlos Pena Filho. Ascenso Ferreira. Carnival.

Resumen: Se pretende, en este trabajo, abordar, comparativamente, aspectos relacionados al carnaval encontrados em La producción poética de tres grandes autores pernambucanos: Manuel Bandeira, Carlos Pena Filho y Ascenso Ferreira, presentando puntos de convergencia y divergência em La representación de referida fiesta popular, analizando los elementos y símbolos elegidos por ellos para darle vida al carnaval en sus poesías. Se nota que, de entre ellos, Bandeira es estudiado de manera profundizada y relevante, mientras que los otros dos autores, aunque teniendo obras enérgicas, son menos explorados académicamente. Lo mismo se percibe del carnaval, en cuanto temática em el campo de las letras y de la literatura, frecuéntemente considerado menos notable en esta área.

Palabras clave: Manuel Bandeira. Carlos Pena Filho. Ascenso Ferreira. Carnaval. 


\section{Nos quatro cantos cheguei e todo mundo chegou: uma introdução}

Inicialmente, este trabalho de análise foi pensado para discutir, comparativamente, apenas os carnavais representados nos poemas Carnaval do Recife, de Ascenso Ferreira, e Soneto principalmente do Carnaval, de Carlos Pena Filho, ambos os poetas pernambucanos que concentraram sua produção, majoritariamente, na primeira metade do século XX, uma vez que a última obra de Ascenso publicada em vida é Poemas, de 1951, e a de Pena Filho é o Livro Geral, de 1959, sendo as duas obras antologias.

A motivação da escolha dos poemas se deu por estes autores terem publicado em períodos semelhantes, assim como por terem passado as suas vidas, logo, suas formações enquanto escritores, no estado de Pernambuco, tendo, deste modo, contato com aspectos culturais similares relacionados ao imaginário do que é o carnaval, ainda que Ascenso Ferreira seja natural de Palmares, zona da mata de Pernambuco (passando a viver no Recife em 1920), enquanto que Carlos Pena Filho é natural da capital, o que de algum modo dará tônicas diferentes em cada uma das representações poéticas analisadas. Ademais, é válido lembrar que os dois poetas foram bastante elogiados em seus tempos, contudo é raro encontrar comentários mais longos sobre suas obras nos manuais de historiografia literária, restringindo-se a rápidas menções, quando ocorrem.

Ao longo da escrita, pareceu-nos, porém, inevitável perpassar esta análise por Manuel Bandeira: escritor que congrega fortuna e sucesso no cânone literário do país, é um dos mais expressivos autores no levantamento do tema do carnaval na Literatura Brasileira, especificamente tratando-se da poesia, cerne desta análise, nos moldes que conhecemos e entendemos a festa no Brasil do século XX em diante e, mais ainda, no estado de Pernambuco, onde ela é indiscutivelmente significativa no imaginário e na vida das pessoas. Bandeira, tão pernambucano quanto os dois primeiros autores, muda-se do Recife em 1902 (entretanto mantém uma relação afetiva com a cidade, evidenciada ao longo de toda a sua obra) indo para o Rio de Janeiro, outra cidade onde a importância do carnaval é indiscutível, e começa sua produção em período anterior ao de Ascenso e Carlos Pena. Posteriormente, os três seguirão em atividade poética contemporânea e 
Manuel Bandeira terá com eles relações de estreita convivência: Ascenso Ferreira publica seu primeiro livro, Catimbó, no ano de 1927, incentivado por Bandeira', a título de exemplo. Por outro lado, o mesmo Ascenso também é personagem do poema A lua, de Carlos Pena filho (s.d. p. 132), denotando, assim, a proximidade do trio de poetas. Seguem-se os versos:

\author{
Era uma lua tão grande \\ de tão vermelha amplidão \\ que mesmo Ascenso Ferreira \\ comendo só a metade \\ morria de indigestão. \\ (PENA FILHO, s.d., p. 132)
}

Estes versos, parte do conjunto de poemas intitulado Guia prático da cidade do Recife, brincam com a fama de comilão e boêmio do poeta de Palmares. “A glutonice de Ascenso era marca registrada no Recife”. (CORREYA, 2001, p. 96).

Bandeira, no ano de 1919, publica o livro intitulado Carnaval, com referências diversas, diretas ou indiretas, à festa e elementos pertencentes a ela, como o nome deixa claro. Esta obra ainda tem constitutivos parnasianosimbolistas, marcantes no início da produção do autor, mas já conta com um processo de libertação destas estéticas, começando a engatinhar no Modernismo, que será plenamente materializado na obra do autor com Libertinagem, de 1930.

Desse modo, os poemas de Carnaval têm formatações e atmosferas diferentes entre si e os poemas de Ascenso Ferreira e Carlos Pena filho dialogarão com os poemas de Manuel Bandeira ora pela formatação, ora pela linguagem utilizada pelos autores.

Sublinhamos que ainda que o carnaval pareça amplo o suficiente para ser delineado como um motivo, Machado e Pegeux (1988, p. 117) definem-no como "tudo aquilo que precisamente não intervém no plano das estruturas, dos princípios organizadores do texto", salientamos que neste trabalho, trataremos o carnaval como um tema, uma vez que "deverá chamar-se tema a tudo aquilo que

\footnotetext{
${ }^{1}$ Segundo a pesquisadora Semira AdlerVainsencher, em artigo do site da Fundação Joaquim Nabuco, na página dedicada a Ascenso Ferreira.
} 
é elemento constitutivo e explicativo do texto literário, elemento que ordena, gera e permite produzir o texto" (MACHADO e PEGEUX, 1988, p. 117). Deste modo, se é fundamental o vínculo existente entre tema e estrutura de uma obra, percebemos, assim, que tanto os poemas do livro de Manuel Bandeira que serão analisados, quanto os poemas de Carlos Pena Filho e Ascenso Ferreira, são estruturados a partir da perspectiva que cada um dos autores tem do carnaval, permitindo, através disso, a construção dos textos ${ }^{2}$.

Também é válido lembrar que

os temas não podem aparentar-se - isto é, adquirir uma significação comum - senão em certas épocas, o que quer dizer, na realidade, que um motivo não lhes é necessariamente comum se lhes torna comum, e isto em função das correntes de ideias do tempo. (TROUSSON, 1988, p. 24)

No nosso caso, o marco temporal, a primeira metade do século $\mathrm{XX}$, mais precisamente os 40 anos que separam as publicações de Carnaval e do Livro Geral, é fundamental para que possamos estabelecer um diálogo entre as obras dos poetas, observando os pontos de convergência e divergência nas representações desta festa popular ${ }^{3}$, que tem uma vivência tão específica e, às vezes tão contrastante dentro de si mesma, dado que observaremos ao longo das análises.

Assim recorda tudo o que passou: as variadas faces do Carnaval de Manuel Bandeira

\footnotetext{
${ }^{2}$ Vale salientar aqui que, nas pesquisas para a escrita deste artigo, descobriu-se um poema do parnasiano Raimundo Correia, intitulado Tristeza de Momo, publicado no livro Aleluias, de 1891, anterior ao livro de Bandeira. Esse texto, porém, não nos parece utilizar o carnaval como elemento estruturador, mas sim como um elemento acessório.

${ }^{3}$ Observamos, assim, que, sendo Carnaval um tema, as festas populares seriam o motivo.
} 
Carnaval, publicado antes da guinada modernista, traz ainda uma tendência narrativa e descritiva, de herança parnasiano-simbolista, mantendo, também, por conta disso, um vínculo com as formas tradicionais de versificação, como as quadras e os sonetos. Em contrapartida, "ele utiliza essas formas tradicionais ao mesmo tempo em que recorre ao vocabulário popular, isso acaba permeando-as de um novo sentido" (ROCHA, 2014, p. 130), quebrando a lógica das estéticas poéticas de fins do século XIX. Dessa mistura entre o tradicional e o coloquial, emergem ainda a ironia e o verso livre, sem abrir mão do ritmo. Segundo o próprio Manuel Bandeira (1997, p. 319-20), Carnaval“é um livro sem unidade. Sob o pretexto de que no carnaval todas as fantasias se permitem, admiti na coletânea uns fundos de gaveta, três ou quatro sonetos que não passam de pastiches parnasianos”, assim como se esforça para se aproximar da modernidade.

Pendulando entre a tradição e a libertação, o carnaval presente na poesia de Bandeira publicada no livro que leva o mesmo nome da festa, deste modo, não obedece a uma lógica única, alterando-se entre os poemas, uma vez que "um único tema pode, na mesma época - e por vezes no mesmo autor - ser portador de vários símbolos" (TROUSSON, 1988, p. 26). No caso de Bandeira, os símbolos do Carnaval se alterarão não apenas entre os poemas do livro publicado em 1919, mas ao longo de toda a sua obra, uma vez que este tema será revisitado diversas vezes, mas não comentaremos as reincidências aqui, já que são posteriores às publicações de Carlos Pena Filho e Ascenso Ferreira. Em suma,

O tema do carnaval em Bandeira pode ser visto sob três ângulos diferentes. O primeiro liga-se às personagens e ao ambiente que se percebem nas Fêtes galantes de Verlaine (este é o Bandeira ainda influenciado pela estética simbolista, como bem o caracteriza o seu livro Carnaval.); o segundo tem como inspiração as peças musicais de Schumann (neste momento poderíamos dizer que Bandeira faz seu carnaval através da música romântica.); o terceiro, por fim, é a visão pessoal da festa popular, tal como a conhecemos (quando Bandeira contesta a ordem estabelecida, que é o que mais nos interessa no presente momento). (CAVALCANTI, p. 7, 2009) 
Colombinas, pierrots e arlequins são alguns dos elementos tradicionais que povoam a maior parte dos poemas de Carnaval e remontam a Commediadell'Arte, surgida na Itália do século XVI e desenvolvida na França até o século XVIII, quando entra em declínio, que tornaram-se marcas da festa momesca e servem de eixo para a composição deste livro de Bandeira, uma vez que onze, dos seus trinta e três poemas, referem-se diretamente à estas personagens. Vejamos a primeira estrofe do poema Pierrot Místico:

\footnotetext{
Torna a meu leito, Colombina! Não procures em outros braços Os requintes em que se afina A volúpia dos meus abraços.

(BANDEIRA, 1993, p. 89-90)
}

Os versos desse poema, construídos em oito quadras e metrificados em oito sílabas, nos levam diretamente ao triângulo amoroso renascentista comentado acima: o Pierrot, apaixonado e macambúzio, pede que Colombina não busque outros braços que não os dele. Seguindo os roteiros pré-estabelecidos da Commediadell'Arte, sabemos que estes outros braços são os de Arlequim. Notamos, assim, ao longo dos poemas de Carnaval, alusivos a estas personagens, que "paira a figura espectral de um Pierrot melancólico, que deve quase tudo à tradição simbolista” (CHEQUER, 2013, p. 35) ainda presente na obra de Manuel Bandeira a este tempo.

No poema Pierrette(BANDEIRA, 1993, p. 91), por sua vez, temos outra impressão, divergente do poema anterior. Seguem as estrofes 5-7, que encerram o poema:

\footnotetext{
O sexo obsidente alucina A minha índole surpresa:

As imagens da natureza

São um delírio de morfina.

A minha carne complicada

Espreita, em voluptuoso ardil,
} 


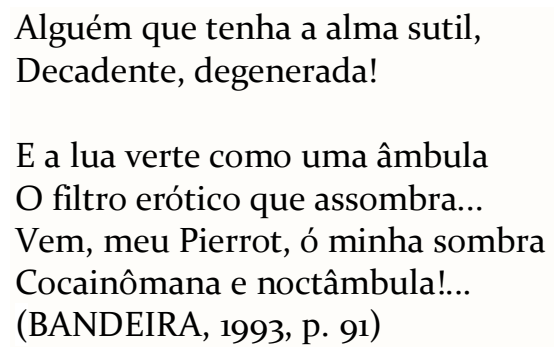

Também metrificado em oito sílabas, mas contando, agora, com sete quadras, em contraste com a figura triste do Pierrô místico, que se repetirá em outros poemas como em A rosa e Pierrot branco, a figura da Pierrette, por sua vez, transita em um outro espaço do carnaval: o dos prazeres. Desta vez, é a figura feminina que chama a masculina, de maneira direta e sensual, sem o tom afetado de lamentação do primeiro poema. Além do teor fortemente erótico, "Pierrette" também conta com referências aos prazeres e ao frenesi causado pelos entorpecentes, também comuns no carnaval desde os perfumes jogados no entrudo $^{4}$ moderno, ao mencionar que as imagens vistas da natureza não são reais, são delírio de morfina, assim como afirma que o Pierrot é a sua sombra cocainômana. Cocaína e morfina, duas substâncias causadoras de euforia e agitação no corpo humano, aproximando, assim, a sensação dos estupefacientes com a sensação do sexo, dois instrumentos de excitação e êxtase nos períodos de carnaval.

Sob outra perspectiva, aquelas personagens, representações e heranças medievais e renascentistas dos bailes de máscaras, entram em contraste com Bacanal (BANDEIRA, 1993, p. 79), poema que abre o livro e seu título remonta às origens do carnaval. Composto com métrica irregular, linguagem menos cheia de erudição e com um tom vibrante, nele, a libertação poética e a libertação do indivíduo andam paralelas, auxiliadas pelas entidades pagãs Baco, Momo e Vênus, elementos profanos e catárticos, que, ao serem aludidos no poema, são sempre precedidos da expressão Evoé: grito de evocação proferido pelas bacantes nos

\footnotetext{
4 "Na Península Ibérica, mais precisamente em Portugal o carnaval era festejado tendo como costume pregar peças. Esta brincadeira recebia o nome de entrudo que significa início. Foi justamente este hábito que os colonizadores europeus - portugueses e espanhóis introduziram na América Latina a partir do século XVI. A brincadeira do entrudo se consistia na prática de jogar água ou pó uns nos outros e em alguns casos lama e até excrementos." (OLIVEIRA, 2012, p. 65)
} 
rituais e que, por extensão, passou a representar felicidade, alegria, exaltação e entusiasmo.

\author{
Quero beber! cantar asneiras \\ No esto brutal das bebedeiras \\ Que tudo emborca e faz em caco... \\ Evoé Baco!
}

(BANDEIRA, 1993, p. 79)

Deparamo-nos, aqui, com um eu-lírico que afirma querer participar de bebedeiras brutais, assim como não se importa em falar asneiras, ou seja, não tem, no período festivo do carnaval, grandes preocupações com a racionalidade nem com as aparências que precisam ser sustentadas nos dias comuns, dado o princípio da inversão ${ }^{5}$, próprio da festa, protegido e exaltando Baco, o deus romano do vinho, representado como uma figura festiva e boêmia, símbolo, também, do hedonismo.

Na estrofe seguinte, nos deparamos com Momo. A deusa, que personifica o sarcasmo e a ironia na antiguidade, torna-se símbolo no carnaval na figura, já masculina, do Rei Momo: imagem burlesca, alegre, foliona e associada às máscaras. Contudo "seus atributos reais no carnaval estão subvertidos, Momo é o rei do 'mundo às avessas"' (CAVALCANTI, p. 6, 2009):

\footnotetext{
Lá se me parte a alma levada

Notorvelim da mascarada.

A gargalhar em doudo assomo...

Evoé Momo!
}

(BANDEIRA, 1993, p. 79)

\footnotetext{
5 "Em uma sociedade extremamente hierarquizada e desigual, o Carnaval permitia, mais ainda na época da ditadura militar, a inversão social no imaginário do povo: durante os 4 dias de Carnaval, os pobres que habitam as favelas do Rio de Janeiro desfilam na Avenida vestidos de Reis, Rainhas, Vedetes, com roupas coloridas e ricamente adornadas, ocupando uma posição central na cidade. Os ricos e a classe média pagam ingressos bem caros para vê-los desfilar nestes dias e, assim, os últimos se tornam os primeiros durante um certo período de tempo, quando dominam a cidade com suas roupas coloridas, música, alegria e tradições."
}

(DAMATTA, 1979, p. 132) 
A imagem do baile representada acima é caótica, inebriante, frenética. A alma, os dias comuns, a consciência individual são sorvidos pelo redemoinho do conjunto festivo. O torvelim (forma oralizada de torvelinho) dos mascarados, ou seja, dos brincantes, arrebata o eu-lírico que, ao perceber-se na situação, só tem como reflexo gargalhar impetuosamente, comemorar e deixar-se fazer parte da atmosfera inebriante.

Por fim, o último ser mitológico a despontar no poema é Vênus, deusa do amor, da beleza e associada ao erotismo:

\section{Lacem-na toda, multicores As serpentinas dos amores, Cobras de lívidos venenos... Evoé Vênus!}

(BANDEIRA, 1993, p. 79)

As serpentinas coloridas aproximam-se, em formato, das cobras e serpentes e, segundo Jean Chevalier (1986, p. 925), o símbolo da serpente representa "lo raro, incomprensible, o misterioso". A cobra, em algumas culturas ancestrais, ainda segundo Chevalier (1986), é uma abstração encarnada: representada por uma linha, sem começo nem fim, assim como a serpentina no carnaval, que dança quando é jogada no ar com trajetória indefinida. A cobra e a serpentina estão, aqui, metamorfoseadas uma na outra, nos levando aos venenos turvos da conquista e do erótico carnavalesco. Tal qual a serpente que, quando desperta "silba y se empina, y laascensiónsucesiva de loschakrastiene lugar: es la subida de la libido, lamanifestación renovada de la vida" (CHEVALIER, 1986 p. 926), a serpentina lançada em movimento pujante manifesta a elevação dos sentidos intensos de euforia.

Caso os poemas de Carnaval fossem escolhidos aleatoriamente por um leitor desavisado, dificilmente seriam agrupados na mesma obra, dada a aguda diferença de forma e atmosfera entre eles, evidenciando a falta de 
homogeneidade que compõe o livro. Se de um lado alguns poemas evidenciam "um Carnaval estilizado com seus símbolos (Pierrô, Arlequim, a dama branca) que lembram escritores modernistas portugueses como Almada Negreiros ou fazem pensar em Schumann com seus improvisos e quebras melódicas” (STEGAGNO-PICCHIO, 1997, p. 492), do outro temos, ainda, na mesma composição "Sonho de uma terça feira gorda", "Poema de uma quarta feira de cinzas", "Ceia", que nos colocam em contato com outras tantas facetas da festa, sejam irônicas, eróticas, melancólicas, ou fantasiosas, assim como um baile de carnaval, em que as imagens registradas por Bandeira continuam despontando e sendo ressignificadas constantemente, a cada período momesco.

Eu Imperador, você Imperatriz: Carlos pena filho e o carnaval das fantasias

Carlos Pena Filho talvez seja um dos poetas mais injustiçados das nossas letras. Morto prematuramente em um acidente de automóvel, aos 31 anos, em 1960, poucas são as referências atuais feitas ao poeta que foi, a seu tempo, intensamente elogiado e possui uma obra extremamente vigorosa e expressiva em lirismo, apesar de breve em volume. Pena Filho tem uma escrita fronteiriça: ao produzir, lança mão de recursos extraliterários, em aproximações com a música vale lembrar que ele compôs, entre outras, a marchinha de carnaval $A$ mesma rosa amarela com Capiba -, assim como recursos plásticos e visuais, num "namoro constante com a pintura, metaforizado através da insistente alusão às cores em seus versos" (QUEIROZ, 2010, p. 25), sendo o azul a mais recorrente. Os tons e os matizes são elementos fundamentais em suas poesias, de linguagem fluida, musical e pictórica e onírica, desembocando ainda "numa espécie de surrealismo irrealizado e programático" (MONTEIRO, 2005, p. 9). 
Em Soneto principalmente do carnaval (PENA FILHO, S.d. p. 119), publicado no ano de 1952, no livro O tempo da busca, é perceptível a construção formal da poética clássica - o soneto, como o título deixa claro - com versos decassílabos e rimas interpoladas, abandonando o experimentalismo da geração de 22 e o regionalismo de 30 :

\begin{abstract}
Essa preocupação orgânica em trabalhar formas fixas, em engordar o rimário e a métrica consagrados pela poética tradicional - e talvez já demasiadamente empregados através de séculos, escolas literárias e gerações -, faz com que ele prescinda de arcabouços formalísticos e efeitos gráficos e visuais latentes, que permeiam, na década de 50, o ânimo e a postura das vanguardas. Estas, por sua vez, se reivindicam experimentalistas, polêmicas e inventivas (MONTEIRO, 2005, p. 7-8).
\end{abstract}

Num período em que os recursos visuais concretistas estão em alta, o poeta termina por se filiar esteticamente a um Parnasianismo tardio, presente na produção de alguns escritores da geração de 45, além de ser, em questões estilísticas, influenciado pelo Simbolismo francês. Apesar disso, vemos na sua obra duas vertentes:

A primeira delas envolve uma orientação analítica que começa a se definir no que existe de particularmente revelador no discurso lírico subjetivista praticado pelo poeta, originário de sua compulsão anímica e espiritual, levando-o a se exprimir numa fala que privilegia a absorção do mundo psíquico autocentrado e narcísico. A segunda vertente analítica tende a revelar os poemas de nítido conteúdo social, de sabor e referência históricos. Em tais poemas, são mantidas conexões definidoras com a cultura popular, que desemboca, por sua vez, numa visão regionalista, contudo participante, derivada diretamente da contemplação ativa de ambientes rurais, onde prevalecem figuras mitológicas e personagens insignes do imaginário nordestino (MONTEIRO, 2005, p. 3).

Possivelmente, sua vinculação a essa visão regionalista e popular, menos árida, seca e paisagística, que se afasta daquela dos anos de 1930, se dá devido à amizade com intelectuais como Ariano Suassuna e Gilberto Freyre. O poema aqui analisado engana: para um leitor contemporâneo e menos atento, talvez não 
existam marcações espaciais ou temporais, bem como talvez não exista nenhuma referência direta ao popular. Porém, tendo Carlos Pena uma vida cultural e boêmia intensa na cidade do Recife, podemos crer que Soneto principalmente do carnaval está impregnado de conexões com o imaginário da região sobre esta festa. O poema é, em sua completude, uma representação incrivelmente plástica, quase um quadro pintado em palavras, dos dias de carnaval, enquanto o eu-lírico observa o alvoroço das fantasias e sente a ausência do passado. Nos dias do reinado de Momo, não existe outro tempo, passado ou futuro, somente a realidade latejante da folia de agora.

Do fogo à cinza fui por três escadas e chegando aos limites dos desertos, entre furnas e leões marquei incertos encontros com mulheres mascaradas. (PENA FILHO, S.d. p. 119)

Em “Do fogo à cinza fui por três escadas” (PENA FILHO, S.d. p. 119), a referência é clara à duração do período carnavalesco. $\mathrm{O}$ fogo, termo que lembra a expressão popular fogoso, como um sinônimo de entusiasmo, é o mesmo fogo da avidez do início da festa que se torna cinza na quarta-feira, dia que finaliza a festa da carne e inicia o primeiro dia da quaresma, quando se acaba a esbórnia, dando lugar às questões do espírito que se prepara para a semana santa. Se nos dias atuais o carnaval no Recife começa, oficialmente, na sexta-feira que antecede o Sábado de Zé-Pereira, quando ocorre a abertura (é válido lembrar que a abertura oficial de Olinda acontece na quinta), no período em que o poema foi escrito, a abertura do carnaval acontecia na madrugada do sábado para o domingo, com a saída da Troça Cariri Olindense ${ }^{6}$, ainda em atividade, que desfila portando a chave do carnaval pelas ruas de Olinda. São, então, as três escadas os três dias de carnaval, em que o folião vive a brincadeira num ânimo ascendente, representado

\footnotetext{
${ }^{6}$ A Troça carnavalesca mista Cariri Olindense foi fundada em 15 de fevereiro de 1921 e é uma das mais antigas agremiações do carnaval de Olinda saindo às $4 \mathrm{~h}$ do domingo de carnaval. Numa dissidência com a diretoria desta troça, fundou-se o Clube carnavalesco de alegoria e crítica Homem da meia noite, em 02 de fevereiro de 1931, com saída pontualmente à meianoite entre o sábado e o domingo, numa tentativa de desbancar o Cariri Olindense na abertura do carnaval. Na atualidade, as diretorias das agremiações reconciliaram-se e o Homem da meia noite leva, no seu desfile, a chave do carnaval até a sede do Cariri, que desfila com ela pelas ruas da cidade. O Galo da Madrugada, maior símbolo do carnaval recifense e que abre o carnaval no sábado de Zé Pereira só seria fundado no ano de 1978.
} 
pela escada, até a chegada da quarta-feira que transforma, abruptamente, a alegria em cinza.

Ademais, é no carnaval o período em que as fantasias, não somente de vestir, mas a fantasia de uma para-realidade, que é completamente verdadeira durante os dias momescos, abafa a realidade cotidiana desértica. Assim, das furnas, ou seja, da escuridão e do isolamento habitual, surgem encontros duvidosos, uma vez que, ao utilizar as máscaras durante festas, talvez o encontro nunca seja com a mulher certa, já que o rosto não é visto.

\author{
De pirata da Espanha disfarçado \\ adormeci panteras e medusas. \\ Mas, quando me lembrei das andaluzas, \\ pulei do azul, sentei-me no encarnado. \\ (PENA FILHO, S.d. p. 119)
}

Assim como as mulheres mascaradas da primeira estrofe, o eu-lírico também veste e vive as fantasias do período de carnaval disfarçado de pirata espanhol, abatendo panteras e medusas. Os dois elementos femininos abatidos, aqui, também dão margem à observação de um erotismo sutil e delicado presente na obra de Pena Filho, já apontado por Manuel Bandeira (1997, p. 275) referindose ao poema Retrato Breve: "nunca pensei que se pudesse pôr tanta beleza no imemorial e sempiternal gesto de iniciação erótica”. Todavia, o dado se estende a tantos outros textos em que são delineadas mulheres, gestos insensatos e corpos incendiados ${ }^{7}$.

A pantera é um felino, família de animais que tem uma carga simbólica de sensualidade, mas também carrega o estigma de ser ardiloso e traiçoeiro. Já a medusa, na mitologia grega, é um terrível monstro que, ao ser observada, quem a olhasse transformava-se em pedra. Medusa, porém "fora outrora uma linda donzela, que se orgulhava principalmente de seus cabelos, mas se atreveu a competir em beleza com Minerva, e a deusa privou-a de seus encantos" (BULFINCH, 2006, p. 121). A pantera e a medusa, juntas, levam-nos a pensar nas primeiras mascaradas, com quem encontros incertos foram marcados. Depois de

\footnotetext{
${ }_{7}^{7}$ Versos dos poemas de Carlos Pena Filho Soneto do desmantelo azul e Carolina, a cansada, respectivamente. 
adormecidas, numa metáfora, também ao ato sexual, as duas imagens de lascívia e apuros, ou seja, depois da saciedade, o eu-lírico que assume, neste dia de carnaval, a nacionalidade espanhola, encontra conterrâneas andaluzas, lançandose do azul num movimento impulsivo. Segundo Jean Chevalier (1986):

El azul es el más profundo de los colores: en él la mirada se hunde sin encontrar obstáculo y se pierde en lo indefinido, como delante de una perpetua evasión del color. El azul es el más inmaterial de los colores: la naturaleza generalmente nos lo presenta sólo hecho de transparencia, es decir de vacío acumulado, vacío del aire, vacío del agua,' vacío del cristal o del diamante. El vacío es exacto, puro y frio. El azul es el más frio de los colores, y en su valor absoluto el más puro, aparte del vacío total del blanco neutro (Chevalier ,1986, p. 163).

O azul, ao mesmo tempo em que representa a profundidade e o infinito, representa, também um acúmulo de vazios, como parecem ter sido as experiências com a Medusa e a Pantera. Assim sendo, o eu-lírico atira-se para as andaluzas e senta-se no encarnado, cor que "encarna el ardor y labelleza, lafuerza impulsiva y generosa, eleroslibre y triunfante" (CHEVALIER, 1986, p. 889), encerrando o momento erótico de maneira apoteótica, como as melhores festas de carnaval.

Para além da carga simbólica das cores e das fantasias, acima mencionadas, o segundo quarteto também esconde duas referências a elementos da cultura popular: as Andaluzas ${ }^{8}$, além de ser a fantasia da amante do eu-lírico espanhol, nomeavam um bloco dos anos de 1920, as Andaluzas em folia. As agremiações de frevo do carnaval pernambucano dividem-se, fundamentalmente, em três grupos ${ }^{9}:$ troças carnavalescas, clubes de frevo, e blocos carnavalescos mistos. O último grupo, os Blocos carnavalescos mistos, surge por volta da década de 1920 com uma intenção:

\footnotetext{
${ }^{8} \mathrm{O}$ bloco das Andaluzas é citado nos frevos Valores do passado, composto por Edgar Morais, gravado em 1973, e no frevo Evocação no1, de Nelson Ferreira, gravado em 1957. Ambas as composições resgatam nomes de vários blocos do início do século XX em seus versos, alguns ainda em atividade, outros já extintos.

${ }_{9}$ Informações retiradas do vídeo Bloco, Troça ou Clube... saiba quem é quem no frevo pernambucano, de Otávio Bastos, disponível em: <https://www.youtube.com/watch?v=6A1sTkGSnaE> Acesso em: 24/01/2019>.
} 
O adjetivo "Mistos" é usado para caracterizar a participação de homens e mulheres na agremiação unidos sob o mesmo interesse: ocupar as ruas da cidade durante o carnaval. Esse uso tornou-se necessário para diferenciar esse tipo de agremiação daquelas que eram exclusivamente masculinas, podendo ser considerado como um reflexo da ampliação da atuação das mulheres nos espaços da cidade (PALMEIRA, 2014, p. 3742).

Deste modo, Andaluzas no poema representa um duplo: no plano simbólico, a fantasia da amante conterrânea e ideal, que se relaciona com o eulírico fantasiado de Espanhol. No plano do tangível, um bloco de carnaval em que a participação e a atuação das mulheres era permitida, uma vez que elas eram - e ainda são - o coro principal que entoava os frevos-canção ao longo do desfile.

Em contrapartida, a estrofe termina com a dupla de cores azul e encarnado, que são as cores dos cordões do Pastoril, um dos principais espetáculos populares do nordeste do Brasil, que compõe o ciclo natalino. Em Pernambuco, este folguedo, ao longo dos séculos, assume duas versões, uma sagrada/religiosa, habitualmente representado por crianças, e uma profana, repleta de canções de duplo sentido. Assim sendo, o eu lírico pula do primeiro grupo, do azul sagrado e infantil natalino, para o segundo grupo, vermelho, vivo, profano, sentando confortavelmente na sensualidade carnavalesca.

\footnotetext{
Respirei as ciganas inconstantes e as profundas ausências do passado, porém, retido fui pelos infantes (PENA FILHO, S.d. p. 119)
}

No carnaval de Carlos Pena Filho, as fantasias transpassam-se umas nas outras, descontinuamente: seja o próprio eu-lírico-pirata, sejam as andaluzas, as mascaradas, panteras, medusas ou leões. É interessante pensar que, neste terceto, a fantasia aludida é a da cigana. Mas diferente das ciganas do imaginário popular, que leem mãos e preveem o futuro, as ciganas do poema são inconstantes. Além delas, que são respiradas, absorvidas, é respirada e absorvida a ausência do passado, uma vez que no carnaval, como comentado anteriormente, o que 
importa é o tempo presente, a festa que se vive no agora, apartando-se, durante a festa, da realidade habitual nas suas amarras e consequências.

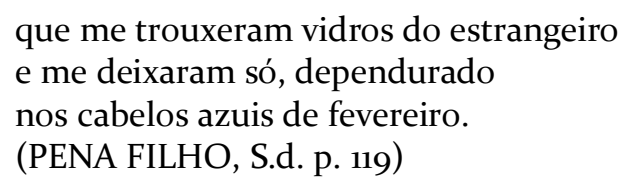

O azul, além de simbolizar o infinito em que tudo se perde, é também "símbolo constante de transcendência" (DIAS, 2014, p. 124), e é esta cor que encerra o poema. Da mesma forma que as serpentinas enrolam e envolvem as pessoas nos salões, os cabelos de fevereiro envolvem o folião que transcende e supera sua própria existência cotidiana na festa, assumindo a identidade da máscara ou da fantasia que usa, numa vida nova que só é possível durante o reinado de Momo.

Tomar umas e outras e cair no passo: o carnaval popular de Ascenso Ferreira

Publicado em 1927, o livro Catimbó é modernista em toda a sua força e repleto de referências a aspectos culturais da vida do nordeste, unindo ideias regionalistas e do Modernismo. Ligado a intelectuais da semana de 22, como Mário de Andrade, Tarsila do Amaral e Manuel Bandeira, Ascenso se impregna dos ideais daquela estética e produz uma poesia experimental, de versos livres e cheia de inovações técnicas. Um dos aspectos mais encantadores da escrita de Ascenso é a maneira como ele se utiliza do folclore e a cultura popular como matéria de inspiração para os seus textos, sem ser clichê ou caricato, harmonizando a linguagem popular e a culta, cinzelando o ritmo e as imagens criadas de maneira que quase é possível transportar-se para a cena descrita. Sobre 
a composição de Catimbó, Mário de Andrade (apud CORREYA, 2001)) fez a seguinte consideração:

\begin{abstract}
A bonita força lírica com o cheiro profundo de terra, os efeitos orais de todo gênero, dizeres antiquados, modismos sintáticos ou vocabulares originados da incultura popular, chaves-de-ouro, seu rapsodismo cantador, um compromisso estabelecido entre o verso metrificado e o verso livre, todas as suas soluções rítmicas [...] (ANDRADE apud CORREYA, 2001, p.38-9).
\end{abstract}

É impossível pensar a produção de Ascenso Ferreira sem fazer uma conexão direta com a terra e Catimbó é uma obra que traz referências diversas a folguedos e manifestações como o reisado, o São João e o Bumba meu boi, que nomeiam alguns dos poemas e, entre eles, está Carnaval no Recife. Câmara Cascudo (1999), no seu Dicionário do folclore brasileiro, assim define o carnaval da cidade: "O carnaval da participação coletiva popular na onda humana que se desloca, contorce e vibra na coreografia, a um tempo pessoal e geral do frevo, com a sugestão irresistível de suas marchas-frevo pernambucanas, insubstituíveis e únicas." (CASCUDO, 1999 p. 248). O texto parece seguir a lógica da definição de Cascudo: o coletivo é a chave deste poema, onde tudo parece acontecer simultaneamente, assim como é no carnaval brincado nas ruas do Recife.

Inicia-se, então, Carnaval do Recife (FERREIRA, 1995, p. 52-53) com referências ao carnaval tradicional europeu, vistas antes em Bandeira, mas agora sem as feições glamorosas dos nobres renascentistas italianos que saíam mascarados para se misturar ao povo, descritas, como visto, em Pierrot místico. Com Ascenso, os elementos populares nordestinos tomam as rédeas da festa, subjugando as personagens da Commedia dell'arte, aniquilando-as de maneira violenta:

\footnotetext{
Meteram uma peixeira no bucho de Colombina que a pobre, coitada, a canela esticou! Deram um rabo-de-arraia em Arlequim, um clister de sebo quente em Pierrô! (FERREIRA, 1995, p. 52)
}

A colombina é esfaqueada de maneira brutal, tal qual um bicho, com uma peixeira, e estica as canelas, o que, na linguagem popular, refere-se à morte; 
Arlequim, por sua vez, leva um rabo-de-arraia, golpe de capoeira classificado como um golpe traumatizante (em oposição aos golpes desequilibrantes), utilizado para ferir. É curioso pensar aqui, também, que a capoeira, elemento da cultura negra, abate o elemento branco europeu; No Pierrô, por fim, deram um clister de sebo quente. Clister é outra designação para enema: sinteticamente, o Pierrô teve sebo quente introduzido em seu ânus, caracterizando algo, também, de violência sexual. Na algazarra momesca, a baderna, a agressividade, a violência também são elementos constituintes "Que tudo emborca e faz em caco..." (BANDEIRA, 1993, p. 79).

Extintos os mascarados estrangeiros, o momento é de festejar com as figuras representativas originárias da região:

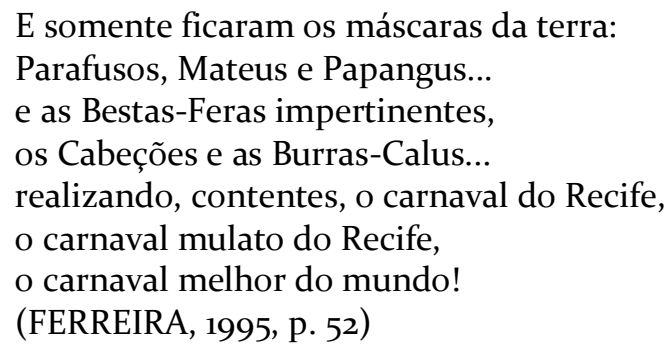

Se o carnaval recifense tem as suas próprias fantasias, descritas ao longo da estrofe, logo, não é preciso importa-las do carnaval europeu, uma vez que são estes símbolos que fazem, contentes, o melhor carnaval do mundo, que também é um carnaval mulato, mestiço, variado. Outra observação que podemos fazer deste trecho é a de que o melhor carnaval do mundo assim o é porque é realizado pelos elementos populares, personificados nas máscaras da terra.

\section{- Mulata danada, lá vem Quitandeira, lá vem Quitandeira que tá de matá! (FERREIRA, 1995, p. 52)}

Nestes dois versos, o que percebemos claramente é a linguagem popular, marca da escrita de Ascenso, reproduzida em “tá de matá”. A “mulata danada”, além de ser um dado de sensualidade "(recorrente nos poemas ascensianos) pode corresponder à mistura de raças que deu origem ao Brasil” (RAMOS, 2013, p. 76). Ademais, à mulata é apontada, pelo eu-lírico, a direção em que vem vindo o bloco 
da Quitandeira. Assim sendo, fica a pergunta: quem será "que tá de matá"? A mulata danada, o frevo rasgado que acompanha a Quitandeira, que vem desfilando, ou a imagem das duas, se deslocando diante do eu-lírico e fazendo a folia?

- Olha o passso do siricongado!

- Olha o passo da siriema!

- Olha o passo do jaburu!

E a Nação-de-Cambinda-Velha!

E a Nação-de-Cambinda Nova!

E a Nação-de-Leão-Coroado!

(FERREIRA, 1995, p. 52)

O sexteto acima, construído em versos livres e mais uma vez reproduzindo a fala do povo, é extremamente imagético. Os passos do siricongado, da siriema e do jaburu são clássicos do frevo dançado na rua e alguns, como o primeiro, dificilmente são executados na atualidade. O frevo é "não uma dança coletiva, de um grupo, um cordão, um cortejo, mas da multidão mesma, a quem aderem todos que o ouvem, como se por todos passasse uma corrente eletrizante" (CASCUDO, 1999, p. 414). Assim, a impressão que temos dos primeiros três versos é a de ver a multidão fervendo enquanto dança. Em contrapartida, os três últimos versos trazem referências ao maracatu: $O$ Cambinda velha e o Leão coroado, que ainda está em atividade e, fundado em 1863, é uma das mais antigas nações de maracatu do país, ambos de baque virado; e o Cambinda Nova, maracatu de baque solto, na atualidade chamado de Cambinda Brasileira. Temos, portanto, nestes versos, uma amostra do frenesi e da mistura de componentes culturais que formam o carnaval recifense.

\footnotetext{
- Danou-se, mulata, que o queima é danado!

- Eu quero virá arcanfô!

Que imensa poesia nos blocos cantando:

"Todo mundo emprega

grande catatau,

pra ver se me pega

o teu olho mal!"

- Viva o Bloco das Flores! Os Batutas!

Apois-fum!

(Como é brasileira a verve desse nome: Apois-fum!)

E o Clube do Pão Duro!

(É mesmo duro de roer o pão do pobre!)

FERREIRA, 1995, p. 52-53)
} 
As agremiações (as nações, os blocos e o clube), nas duas estrofes apresentadas, são a matéria principal. Se o frevo de rua já figurou no poema anteriormente, os blocos líricos e as marchinhas cantadas nas ruas assumem, agora, seu lugar na festa multifacetada descrita por Ascenso e, a exceção do Apois-fum, os blocos referenciados continuam em atividade. O Batutas, infelizmente, hoje entrou em decadência, mas o Bloco das Flores é um dos maiores blocos líricos do circuito do carnaval recifense.

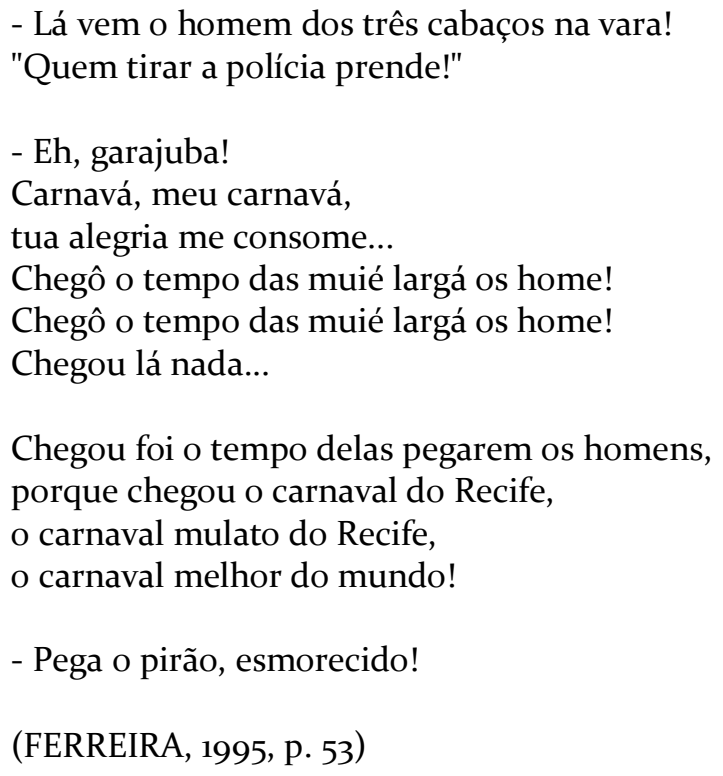

Carnaval do Recife é finalizado com o retorno da representação da linguagem popular, nas expressões carnavá; chegô; muié; larga; home, que, ademais, dá certo ritmo ao trecho. Também é notável o tom jocoso, intrínseco aos dias do reinado de Momo, que permeia os versos acima reproduzidos. Nos dois primeiros, é notável, inclusive, a inclinação quase pornográfica do homem dos cabaços na vara, valendo ressaltar que, no popular, cabaço é referente à virgindade feminina. Lembrando que o poema é publicado em 1927, fica claro o porquê de a polícia prender quem tirá-los. No carnaval, também, reina a inversão. De papeis trocados, assim, é o tempo em que as mulheres largam e pegam os homens a seu gosto, assumindo posturas masculinas no que diz respeito à conquista.

Para o eu lírico que canta este poema, o carnaval mulato, mestiço, erótico e múltiplo do Recife é o melhor do mundo e o final da leitura deixa essa sensação. Ascenso Ferreira constrói o poema como um turbilhão de imagens e informações 
bombardeadas de forma quase simultânea que nos invadem de maneira desordenada, musical, colorida e dinâmica, quase como o desfile das agremiações que passam pelas ruas. E Recife, cidade em que "desde novembro que o pessoal, carnavalizado totalmente, caiu no 'frevo', e não tem sábado sem cordão mexemexendo" (ANDRADE, 2015, p. 303), se houver, ainda, algum esmorecido amofinado, sirva-se um pirão para sustentar as forças e brincar até o último dia de folia.

Adeus, adeus, minha gente, que já cantamos bastante: algumas considerações finais

Festa de momo, folia, folguedo. Tão entranhado culturalmente, muitas vezes o carnaval é visto como algo que está "no sangue" das pessoas, não as levando a problematizá-lo ou a pensar as suas origens, os seus símbolos e seus significados. Adiante, sendo uma festa popular, é percebida amiúde como algo de menor valor nos meios acadêmicos, sobretudo nos campos que estudam as Belas Artes, sendo encarcerado quase que somente no campo da história e da antropologia, quando lhe é dado alguma importância. A despeito da visão inferiorizante desta, que é a maior festa popular do país, Manuel Bandeira, Ascenso Ferreira e Carlos Pena Filho, grandes nomes da Literatura Brasileira, foliões no carnaval e na obra, sublimemente a utilizam como um vigoroso tema em suas produções, cada qual a seu modo.

Bandeira abre os caminhos da nossa análise transitando entre a forma tradicional e a libertação, oferecendo ao leitor desde os ostentosos elementos primordiais que compõem a comemoração, como os Pierrots e Arlequins, as bebedeiras, as gargalhadas e a esbórnia, que em nada parecem fazer parte da mesma celebração dos mascarados, em que se esbalda o folião perdido no espaço festivo. Por outro lado, Carlos Pena Filho, brincante sem passado nem futuro, 
pinta um quadro utilizando palavras em vez de tintas, compondo com um lirismo apuradíssimo e singelo, a tela das fantasias que se esbarram umas nas outras no reinado momesco. Por fim, Ascenso Ferreira dá voz ao povo, às ruas, aos folguedos, às cores. Ascenso, num ritmo enérgico de escrita, reproduz a grandiosidade da festa que não acontece em nenhum baile, mas em todos os espaços da cidade, num poema em que quase é possível ver e ouvir as troças e os maracatus desfilando nas ruas do Recife. Os três poetas pernambucanos, unidos por uma única festa nos seus diversos matizes, seja o da tradição, seja vivendo prazeres proibidos na vida cotidiana, seja fazendo mesura na ponta do pé ${ }^{10}$, transportam o leitor para frente do calendário, deixando-o agoniado a contar os dias que faltam para a chegada de fevereiro.

\section{Referências}

ANDRADE, Mário de. O turista aprendiz. Brasília, DF: Iphan, 2015.

BANDEIRA, Manuel. Estrela da vida inteira. Rio de Janeiro: Nova fronteira, 1993.

BANDEIRA, Manuel. Seleta de prosa. Rio de Janeiro: Nova fronteira, 1997.

BASTOS, Otávio. Bloco, Troça ou Clube... saiba quem é quem no frevo pernambucano. 2017. (4m 27s). Disponível em: <https://www.youtube.com/watch?v=6A1sTkGSnaE>. Acesso em: 24/o1/2019.

BULFINCH, Thomas. O livro de ouro da mitologia: histórias de deuses e heróis. Rio de Janeiro: Ediouro, 2006.

CASCUDO, Luis da Câmara. Dicionário do folclore brasileiro. Rio de Janeiro: Ediouro, 1999.

CAVALCANTI, L. M. D.. O carnaval na poética de Manuel Bandeira. DarandinaRevisteletrônica, v. 01, p. 01-15, 2009.

${ }^{10}$ Verso do frevo Bom demais, composto por J. Michiles e conhecido na voz de Alceu Valença. 
CHEQUER, G. O Carnaval de Manuel Bandeira e a commediadell'arte. Soletras. Universidade Estadual do Rio de Janeiro, n. 25, p. 32 - 48, jan - jun, 2013.

CHEVALIER, Jean. Diccionário de los símbolos. Barcelona: Editorial Herder, 1986.

CORREYA, Juareiz. Ascenso, o nordeste em carne E osso. Recife: Bagaço, 2001.

DAMATTA, Roberto. Carnavais, Malandros e heróis: para uma sociologia do dilema brasileiro. Rio de janeiro, Zahar Editores, 1979.

DIAS, J.C.T. Soneto do Desmantelo Azul: Um Incurso a Erosfera de Carlos Pena Filho. Revista Ártemis, v. 17, p. 121-128, 2014.

FERREIRA, Ascenso. Catimbó: cana caiana: xenhenhém. 5 ed. Recife: Nordestal, 1995 .

MACHADO, A. M; PEGEUX, D. H. Da literatura comparada à teoria da literatura. Lisboa: Edições 70, 1988.

Monteiro, Luiz. Carlos. Musa fragmentada: a poética de Carlos Pena Filho. Dissertação (Mestrado em teoria da literatura). Centro de artes e comunicação, Universidade Federal de Pernambuco. Recife, p. 99. 2005.

OLIVEIRA, J. L.Pequena história do carnaval carioca: de suas origens aos dias atuais. Encontros, n 18, p. 61-85, 2012.

PALMEIRA, J. D. Blocos Carnavalescos Mistos e as relações de gênero na folia das ruas do Recife na década de 1920. In: 18º Encontro Nacional da Rede Feminista Norte e Nordeste de Estudos e Pesquisa sobre as Mulheres e as Relações de Gênero - REDOR. Anais... Recife, 2014, p. 3740 - 3756.

PENA FILHO, Carlos. Livro Geral. Recife: Editora Raiz, s.d.

QUEIROZ, A. O. Metade roubada ao mar, metade à imaginação: a cidade do Recife por Carlos Pena Filho. Rascunhos Culturais, v. 1, p. 15-28, 2011.

RAMOS, Joranaide. Alves. Ascenso Ferreira: um poeta-cantador da cultura pernambucana. Dissertação (Mestrado em Estudos literários). Faculdade de Letras, Universidade Federal de Alagoas. Maceió, p. 110. 2013. 
ROCHA, M. O. Residualidade literária na poética de Manuel Bandeira. Entrelaces, Universidade Federal do Ceará, n. 4, p. 126 - 141, set. 2014.

STEGAGNO-PICCHIO, Luciana. História da literatura brasileira. Rio de Janeiro: Nova Aguilar, 1997.

TROUSSON, Raymond. Temas e mitos - questões de método. Lisboa: Livros Horizonte, 1988.

VAINSENCHER, Semira Adler. Ascenso Ferreira. Pesquisa Escolar Online, Fundação Joaquim Nabuco, Recife. Disponível em: <http://basilio.fundaj.gov.br/pesquisaescolar/index.php>. Acesso em: 18/o1/2019.

\footnotetext{
* Mestranda do Programa de Pós-Graduação em Letras da UFPE. Graduada em Letras pela UPE e Especialista em Literatura Brasileira pela FAFIRE.
} 